\title{
Thomas Allies, John Henry Newman and Providentialist History
}

\author{
C. D. A. Leighton* \\ History Department, Faculty of Economics, Administrative and Social Sciences, \\ Bilkent University, Bilkent, Ankara, Turkey
}

\begin{abstract}
Summary
This article discusses and evaluates the historiographical work of a leading Oxford convert and Ultramontane, Thomas Allies (1813-1903). An evaluation of Allies by the criteria of the Ultramontane scholarship he endeavoured to practise allows the article to offer an illustration of the difficulty in establishing and maintaining an autonomous Catholic scholarship during the nineteenth century's secularising development of academic activity. It also allows substantial description of the patterns of nineteenth-century Catholic historical thought, noting the strength of its commitment to providentialism and, in particular, its apocalyptic character. An examination of the influences brought to bear on the subject's thought during the formative period of his development as an historian, through his own study and his close friendship with John Henry Newman, indicates the reasons for Allies's ultimate failure either to create a clear and stimulating product of the Ultramontane historical vision or to achieve an academic or popular reputation as an historian. The article argues that an unresolved conflict, between Allies's inclination towards a providentialist historiography consistent with his commitment to a Catholic counter-culture and his willingness to accept, under Newman's guidance, contemporary secular historiographical norms, offers substantial explanation of this failure.
\end{abstract}

Keywords: Catholic historiography; Ultramontanism; New Catholicism; Thomas Allies; John Henry Newman; Oxford Movement.

\section{Contents}

1. Introduction . . . . . . . . . . . . . . . . . . . . . . . . . 248

2. The Ultramontane Scholar and his Task . . . . . . . . . . . . . . 251

3. The Anglican Formation of an Ultramontane Scholar . . . . . . . . . . . . 253

4. The History of Antichrist's Kingdom . . . . . . . . . . . . . . . . . 255

5. The Philosophy of History and Divine Providence. . . . . . . . . . . . 260

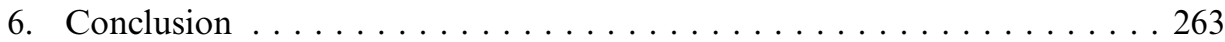

\section{Introduction}

Of the intellectual figures whose identification with the Oxford Movement led them to embrace Catholicism, Thomas Allies was reckoned to be in the first rank.

*E-mail: douglas@bilkent.edu.tr 
John Henry Newman, certainly, placed him with such as Manning, William and Henry Wilberforce, and James Hope-Scott, whose stature and decision commended at least serious attention to the Catholic case against the Church of England. ${ }^{1}$ Indeed, his reputation stretched beyond the shores of England. Der Katholik, from Mainz, observed, as it reviewed his recently published works relating to his conversion, that '[n]o one who is only partially well versed in the English Catholic literature of our times will dispute Mr. Allies' title to be accounted one of its foremost writers'. ${ }^{2}$ His scholarly and literary reputation as a controversialist was enhanced by an ingenuous but well-crafted biographical narrative. His commitment to the Tractarian cause blighted what had been a promising ecclesiastical career, and his conversion to Catholicism - as in the cases of other married clergymen - caused him and his family serious hardship. ${ }^{3}$ Newman attempted to place him in a chair of the Catholic University in Dublin; but, much as he would have preferred such scholarly occupation, ${ }^{4}$ he found the salary earned as secretary to the Catholic Poor School Committee necessary for supporting his family. ${ }^{5}$ The latter half of his life was thus necessarily divided between the labour of establishing an English Catholic school system and his scholarly endeavours. This had been directed by his very limited but extended association with the Catholic University towards the publication of what became an eight-volume study of late antiquity and the early medieval period, entitled the Formation of Christendom. ${ }^{6}$

If one notes that Allies has been described as 'the greatest of the Catholic lay leaders' in nineteenth-century England, ${ }^{7}$ it must also be remarked that he has been very far from attracting attention of the sort given to those for whom comparable claims might be made, such as de Maistre, Veuillot, and Orestes Brownson. The only book devoted to him came from his daughter's pen. Indeed, this lack of attention may be traced back to the latter part of his lifetime; his obituary in the Tablet described his death as 'an event that stirs - at least memories'. True, such remarks have frequently been made about persons who have lived, as Allies did, very long into old age. Yet Allies was primarily a writer, who continued to publish volumes of the Formation of Christendom until not long before his death. In truth, Allies's immense, consuming devotion to history for more than half of his life earned him honours from Leo XIII and plaudits from English prelates, but no great reputation as an historian. Significantly, the obituary spoke very little of him in that capacity. ${ }^{8}$ In private correspondence, Newman - who was responsible for and had directed Allies's entry into historical studies and was the dedicatee of some of the volumes produced - early

\footnotetext{
1 John Henry Newman to Lord Charles Thynne, January 30, 1852 letter and Newman to Mrs William Froude, [1854 or 1855] letter, in Letters and Diaries of John Henry Newman (hereafter L. D.), 32 vols, edited by Charles S. Dessain and others (London, 1961-1972; Oxford, 1973-2008), XV, 25 and XVI, 105-09.

${ }_{2}$ The review was translated and published in the Dublin Review, 3rd series, 4 (October 1880), 243-68.

${ }^{3}$ V. Alan McClelland, "The Most Turbulent Priest of the Oxford Diocese': Thomas William Allies and the Quest for Authority 1837-1850', in By Whose Authority? Newman, Manning and the Magisterium, edited by V. Alan McClelland (Bath, 1996), 273-90. Allies's autobiographical account of his Romeward path, $A$ Life's Decision (London, 1880), remains a fine example of its genre.

4 Thomas Allies to Newman, 1 September 1864, in Newman's Dublin Papers, 49 (3), Birmingham Oratory Archives.

${ }^{5}$ Newman to Allies, 20 March 1855, in L.D., XVI, 418.

${ }^{6}$ Thomas William Allies, The Formation of Christendom, 8 vols (London, 1865-1896). Later volumes bore different titles, though their identification with the entire work was uniformly made clear.

${ }^{7}$ Quoted from Arthur C. F. Beales, in McClelland, 'The Most Turbulent Priest of the Oxford Diocese', in By Whose Authority, 273.

8 Tablet, 20 June 1903.
} 
expressed his disappointment at the results of his actions. Allies probably never came to know Newman's opinion; but he was certainly aware that his publications had been largely ignored by other historians and had failed to achieve the readership he had hoped for. ${ }^{9}$ In short, Allies - a highly gifted writer and an able and dedicated scholar-poured much of life into an historical project which failed to make a substantial impact, in his own lifetime or on later scholarship.

Another related failure is spoken of as the chief matter of the present essay, with a view to comment on Catholic historical scholarship in the era. This was a failure by Allies to realise both his considerable potential and his declared desire, effectively to reassert in his own time the historiographical tradition of Christendom, of accepting the Christian revelation as providing the fundamental, directive data of historical scholarship. For this providentialist historiography continued to serve well the objectives of the Catholicism of his own period, as it adopted a confrontational stance towards an increasingly manifested secularism and laboured to create, in scholarship as in other activity, 'a Catholic subculture cut off from the mainstream' and 'a viable alternative to secular society'. ${ }^{10}$ In the subsuming of the historical study of secular phenomena under Heilsgeschichte, both the historiographical principles adopted and the content of what was produced served the militancy required for such separation.

If Allies failed in this, however, his magnum opus retained an immense amount of evidence of his mental inability to abandon his initial impulse towards the production of providentialist history. This, and the designation he accepted as a 'philosopher of history', might be thought enough to explain the obscurity his work suffered both at the end of the nineteenth century and during the twentieth century when, at least in England, the criteria of academic respectability excluded historians given much to theologising or philosophising. However, the use of such criteria in speaking of Allies now appears unacceptable. Hayden White's unwillingness to separate philosophers of history from previously more commended writers of 'proper' history is common among us, while his further unwillingness to devote attention to those philosophies of history which he designates as 'authoritarian' and failing in 'cognitive responsibility', among which Allies's work would certainly be placed, ${ }^{11}$ seems to be much less than easily justifiable. The present essay therefore attempts to comment on Allies only with reference to criteria that he himself might well have accepted - those utilised by the Ultramontane Catholic scholarship of his day. ${ }^{12}$ It is hoped that a strict confining of consideration of Allies to the world of nineteenth-century Ultramontanism or the 'New Catholicism' has the merit of opening his work as a useful source for the study of the mind of his own period.

The study proceeds by speaking of the tasks faced by the scholars of the Catholic world that Allies inhabited, and going on to point out his capacity and disposition to

\footnotetext{
9 Newman to Canon John Walker, 6 June 1869, and Newman to Allies, 21 May 1882, in L.D., XXIV, 26566 and XXIX, 89.

${ }^{10}$ Richard Schaefer, 'Program for a New Catholic Wissenschaft: Devotional Activism and Catholic Modernity in the Nineteenth Century', Modern Intellectual History, IV, 3 (2007), 435.

${ }^{11}$ Hayden White, Metahistory: The Historical Imagination in Nineteenth-Century Europe, paperback edition (Baltimore, MD, 1975), 23.

${ }^{12}$ It will be sufficient, at this point, to record that Allies explicitly identified himself unreservedly with the term 'Ultramontane' in its most familiar albeit synecdochical sense, with his declaration that it had been his 'work in life to defend the See of Peter'. See Mary H. Allies, Thomas William Allies (London, 1907), 141.
} 
undertake them. The latter parts of the study discuss the substantial but incomplete abandonment of fundamental counter-secular modes of historical thought by Allies. The first was an implicitly apocalyptic interpretation of the history of Christendom, common during the period. The second was a more general assertion of the propriety of providentialist history. Allies, it may be said, though he would doubtless have found such imputed association disturbing, attempted to embrace a position closer to that of those nineteenth-century English Catholic historians who were afterwards more esteemed than he-John Lingard and Lord Acton. In truth, the immediate cause of Allies's partial alterations of mind is not difficult to ascertain. That he did not follow his own path was due primarily to his relationship with Newman, to whom, from young manhood, he possessed a very great personal devotion. Allies's Tablet obituary dwelt a good deal on this friendship, adding a quite accurate suggestion that its subject was inclined to make himself subservient to his distinguished friend's opinions in matters of scholarship. The consequence was the following of a scholarly path far less than harmonious with his cast of mind, with predictably poor results. In fairness to Newman, one might add that manifestations of Allies's willingness to be led came as responses to what Newman clearly regarded as invitations to discussion; such manifestations were apt to surprise him and perhaps left him somewhat uncomfortable. ${ }^{13}$ Newman's own views on the matter of history writing can scarcely be excised from this study, though the description of Allies's thought has been considered of more interest than accounting for it.

\section{The Ultramontane Scholar and his Task}

The scholarship to which Allies aspired to contribute is most interestingly perceived as a constituent part of the Catholic Church's response to the changed circumstances with which the nineteenth century, or what is more comprehensively referred to as 'modernity', confronted it. This response has, of recent years, received the singularly uninformative designation of the 'New Catholicism'. ${ }^{14}$ The term 'Ultramontanism' is more acceptable, as long as it is understood as synecdoche, using a moiety of the phenomenon under discussion. This was the increased attachment to Rome, together with the Roman response to it. The remaining moiety is discerned in placing this within the context of the situations of Catholic communities, increasingly subject to modernity's aggressions and their other responses to them. Such description, it is to be acknowledged, has its difficulties. Ruth Harris, in exploring one very notable manifestation of nineteenth-century Catholicism's response to modernity, adopts the view that the concept of 'modernity' requires serious modification, so that it accommodates this response within it. ${ }^{15}$ This sits ill with the delineation of modernity attempted by the Syllabus Errorum: modernity was what the Church judged necessary to condemn. When the document's final proposition

\footnotetext{
${ }^{13}$ See, for example, Newman to Allies, 5 March 1861, in L.D., XIX, 472-73.

14 See, notably, Christopher Clark, 'The New Catholicism and the European Culture Wars', in Culture Wars: Secular-Catholic Conflict in Nineteenth-Century Europe, edited by Christopher Clark and Wolfram Kaiser (Cambridge, 2003), chapter 1.

${ }^{15}$ Ruth Harris, Lourdes: Body and Spirit in the Secular Age (London, 1999), 12. Such concern with the definition of modernity and with the need to find space within it for phenomena subject to description as 'archaic and retrograde' is now common among scholars in the field of eighteenth- and nineteenth-century Catholicism. See, for example, Darrin M. McMahon, Enemies of the Enlightenment: the French CounterEnlightenment and the Making of Modernity (Oxford, 2001), 197-203; speaking of the nineteenth century, see Schaefer, 'Catholic Wissenschaft', 436.
} 
declared 'modern civilization' incompatible with Catholic Christianity, it had, in seventy-nine preceding propositions, offered a very extensive, if somewhat haphazard and inevitably incomplete, depiction of the former - and it is perhaps best for the historian to remain content with a usage of contemporary combatants. ${ }^{16}$ The pope's private commendation of the interpretation given to the Syllabus by Bishop Dupanloup, who had emphasised that its understanding required observation of its principles in particular circumstances, suggests that Pius was quite aware that for Catholics in the age of Ultramontanism, as for observers from our own postmodernity, the labour of identifying the object of their disparagement could not have a foreseeable end.

The Syllabus was an act of defiance directed against political enemies, particularly in the Italian peninsula, and of condemnation directed against such as 'Acton's circle in England, Montalembert in France and Döllinger's activities in Münich'. ${ }^{17}$ As Gertrude Himmelfarb remarks, its eightieth condemned proposition 'reads like a statement of [...] [Acton's] faith' ${ }^{18}$ However, it should not be forgotten that the Syllabus also had the positive intention of assisting those Catholics who laboured to distinguish between the products of the 'rise of modern paganism'- to use Peter Gay's phrase - and the useful intellectual developments of their times. ${ }^{19}$ In their circumstances, it was a constantly pressing task. They were endeavouring - to state the nature of their labours more comprehensively - to build and intellectually arm a militant society, separate from the one which they perceived apostatising around it. However, merely in that this work was intended as an effective response to secular developments, it necessarily had a close relationship to them. The members of this militant society were to be trained for debate both with opponents and the less than committed; but debate required at least some common ground. Moreover, if training for this intellectual conflict was to be adequate, it was necessary to encourage a measure of internal debate - and thus self-reflection and self-criticism-among militant Catholics themselves, distracting as that might be in the midst of warfare. ${ }^{20}$ The Catholic statesman, Donoso Cortés, might remind bishops that they debased their office by debating rather than teaching; but the censure could hardly be applied to others. ${ }^{21}$ The engaged Catholic thinker and writer, if he had one foot in Eden, was ever obliged to survey the corn and tares compactly grown. Though such difficulties were indeed irremovable, some responses to them were more efficacious in advancing the Catholic cause than others; those to which Allies was himself inclined were so.

Present-day considerations of the Catholic Church's embrace of significant aspects of nineteenth-century modernity find most fundamental its acceptance of the need to rest its social and political authority increasingly on popular commitment. Translated into the demands placed on the Catholic scholarly writer, this meant the possession of the dispositions and skills which could strip down scholarship to produce and clearly present readily graspable concepts. The strength of such concepts was enhanced by being in harmony with existing popular notions

\footnotetext{
${ }^{16}$ A convenient and sympathetic description of the contents of the Syllabus is to be found in Roberto de Mattei, Pius IX (Leominster, 2004), part 2, chapter 2.

17 Friedrich Heyer, The Catholic Church from 1648 to 1870 (London, 1969), 162-65.

18 Gertrude Himmelfarb, Lord Acton: A Study in Conscience and Politics, second edition (Chicago, 1962), 61 .

19 Peter Gay, The Enlightenment: The Rise of Modern Paganism (New York, 1966).

20 Schaefer, 'Catholic Wissenschaft'. See especially 435, 438.

${ }^{21}$ Robert A. Herrera, Donoso Cortes: Cassandra of the Age (Grand Rapids, MI, 1995), 112.
} 
and by providing support for the popularly led resurgence of expression of belief in the immanent supernatural. The writer was to nurture Catholic commitment and forge weapons in the conflicts in which laity and clergy together found themselves engaged.

\section{The Anglican Formation of an Ultramontane Scholar}

Allies came to Catholicism with a highly combatant disposition and the skills that would aid its effective manifestation. His own recording of the period he spent as an Anglican clergyman affords immediate understanding of Alan McClelland's presentation of him as 'turbulent'. A great deal of it is taken up with an account of ably conducted conflicts with his fellow clergymen and his ordinary, Samuel Wilberforce. Allies honestly acknowledged, in concluding the section on his conflict with the bishop, the 'burning anger' he had felt at the time, ${ }^{22}$ while his daughter observed that 'St. Augustine's advice, "Hate the error, love the man," was not always before him in speaking of Bishop Wilberforce[.. . ]'. ${ }^{23}$ Just as noteworthy are his long accounts of his near-annual visits to the European mainland during this period of his life. Earlier visits are recorded in his autobiographical piece, published in 1880, but based on his contemporary journals. A separate volume, published in 1849, was devoted to two of the later trips. The views expressed in this latter volume provided the matter for his chief conflict with Wilberforce. His earlier trips, recorded in A Life's Decision, were chiefly to 'infidel France', where 'revolutionary impiety' was responsible for 'the greatest destruction which has ever fallen on a church[...]' and where that institution's condition and strategies in the counter-campaign could be observed. In the constant comparison between the French church and the Church of England, the latter's participation in this universal struggle against the forces of modern evil appeared close to complete failure. The contrast was not merely in externals. Essentially, he believed, it lay in a supernatural sustaining of the religiosity of the French laity and of the self-sacrificing zeal of France's priests, while England had in practice become so heathenised, so infected with indifference'. ${ }^{24}$ More immediately arresting manifestations of divine aid in 'an age of especial scepticism and unbelief in spiritual agency' were also adverted to in speaking of the Tyrolese stigmatics, Maria Lazzari and Maria Mörl. ${ }^{25}$ Many of the same themes are present in his Journal in France in 1845 and 1848 [...], where, in his introduction, he expounds his motivation in publishing as a desire to call the Church of England to the struggle against the 'common foe' of Anglicanism and Catholicism - the state, French or British - in the process of establishing 'Infidelity'. ${ }^{26}$ The work's character as a piece of encouraging wartime journalism, reporting on the success of an ally, no doubt accounts for the extraordinarily positive presentations of French ecclesiastical institutions which fill much of it. $^{27}$ In brief, even before his conversion, Allies had shown himself

\footnotetext{
22 Allies, Decision, 129-219.

23 M. H. Allies, Allies, 166.

${ }^{24}$ See the account of his visit to France in 1843 in Allies, Decision, 25-41.

25 Allies, Decision, 116-128.

26 Thomas William Allies, Journal in France in 1845 and 1848: With Letters from Italy in 1847; Of Things and Persons Concerning the Church and Education (London, 1849), 1-9.

${ }_{27}$ Cf. Austin Gough on French clerical education in his Paris and Rome: The Gallican Church and the Ultramontane Campaign 1848-1853 (Oxford, 1986), 1-10.
} 
undeterred by conflict, deeply committed to Catholicism's contemporary struggle, and capable of eloquent polemic in the popular tone it had adopted.

Allies, unsurprisingly for one deeply conscious of the immanent supernatural, spoke much of providence in his account of his approach to conversion, observing with reference to his years as rector of Launton that "what God was doing I knew not then, but I know now'. ${ }^{28}$ However, he spoke much too of his studies and in particular of the 'three full years [given] to the dreadful Roman controversy'. ${ }^{29}$ In those years he forged a Catholic apologetic which was, as a later convert put it, 'unique in its adaptation' to English debate, ${ }^{30}$ pre-eminently attractive to protagonists of Ultramontane argumentation, and possessing the appearance of cutting the Gordian knot of controversy. The fundamental character of his approach was established even as he defended his Anglican position. ${ }^{31}$ The matter in dispute was papal authority. By 1850 he was, from a study of the history of the English Reformation, able skilfully to articulate his case that the state's claim to ecclesiastical jurisdiction, without the power of orders, had produced a concealment of the extent of the state's power, which was, in practice, corruptive of Christianity. ${ }^{32}$ This was certainly an argument fundamentally determined by the apocalyptic condemnation of the contemporary European state, which sought to establish Infidelity. It thus showed itself to be under the dominion of Antichrist, identified with the assertion of human reason against the authority of revelation - 'the predicted Lawless One, the Logos, reason, or private judgment of apostate humanity rising up against the Divine Logos incarnate in His Church'. ${ }^{33}$ This apocalyptic understanding of the times, a fundamental characteristic of the Oxford Movement, ${ }^{34}$ led to the inescapable Ultramontane response to it: a devotion to the enduring sacred monarchy, in Rome. In a second volume, also published in 1850 , its claims to authority were defended with considerable patristic scholarship. ${ }^{35}$

Newman greatly appreciated Allies's skills as a learned controversialist and, more than thirty years later, he commended these writings as the 'strongest' piece of English controversial ecclesiology of which he knew. He had earlier pointed out to Francis Burnand, then a comic journalist, the merits of Allies's resting of controversy on argumentation for papal authority. He noted 'the strength of the argument adducible on this point on the Catholic side - and undoubtedly it is most convenient in argument, from its simplicity in itself, in its decisiveness and summariness in its consequences'. He noted, though, that his own approach was different: '[... ] for me, the Church directs me to the Pope, not the Pope [...] to the Church., ${ }^{36}$ If Newman

\footnotetext{
28 Allies, Decision, 14. See also Allies, Decision, 60.

29 Allies, Decision, 79.

${ }^{30}$ Luke Rivington, 'Peter not Caesar: Or, Mr. Allies' Per Crucem ad Lucem', Dublin Review, 3rd series, 24 (October 1890), 243.

31 Thomas William Allies, The Church of England Cleared from the Charge of Schism: Upon Testimonies of Councils and Fathers of the First Six Centuries (London, 1846).

32 Allies's Royal Supremacy Viewed with Reference to the Two Spiritual Powers of Order and Jurisdiction was republished in the more accessible collection of his minor writings entitled Per Crucem ad Lucem: The Result of a Life, 2 vols (London, 1879), I, 83-125.

33 Allies, Church of England Cleared, iii.

34 Christopher Dawson, The Spirit of the Oxford Movement and Newman's Place in History (London, 2001), 142-44. Dawson's conclusion to The Spirit of the Oxford Movement, to which this citation refers, contains further perceptive comment on the closeness of the Movement's thought to Ultramontanism.

35 Allies, Per Crucem, I, 126-272. The volume was entitled The See of St. Peter, the Rock of the Church, the Source of Jurisdiction, and the Centre of Unity.

${ }^{36}$ Newman to [Unknown], [late 1885], and Newman to Francis Burnand, 5 November 1865, in L.D., XXII, 94-97 and XXX, 108-09.
} 
appreciated the effectiveness of his friend's skills, Acton was repelled by this intellectual combatant. Acton contrasted his own inclination to seek out intellectual difficulties in his religion, asserting his purpose to be its defence, with that of Allies, whom he thought assumed 'that there is nothing which cannot be converted into a support of religion' by rhetorical skill. ${ }^{37}$ Allies's recognition of the subjective character of reasoning, ${ }^{38}$ shared with so many other adherents of the Oxford Movement, together with a belief in the greater epistemic authority of revelation, no doubt may be said to have favoured a conscious perception of rational argument as rhetorical device, to be used in the service of the greater authority. Acton was inevitably offended on finding a practice of treating the fruits of the rationalist, inductive method in which he believed so fervently, if not with contempt, at least in a cavalier fashion.

\section{The History of Antichrist's Kingdom}

In light of the views he expressed even while still an Anglican, it occasions little surprise to find Allies, very soon after his conversion, expounding (albeit briefly) a version of that understanding of Christendom's history which was so characteristic of Ultramontane thought. Elements of this understanding have been commented on; but a partial view distorts it, sometimes to the point of rendering it absurd. For Austin Gough and Geoffrey Cubitt, for example, it was constituted by an interpretation of la Révolution, the origins of which are to be traced to the very widely read writer of the 1790s, Augustin Barruel. While his conspiracy theory had exposed merely the philosophes and some of their accomplices as agents of the catastrophe, it came to be extended into the whole early modern period and the detected conspiracy acquired a direction by supernatural evil. ${ }^{39}$ This is better given the name, pace Cubitt, not of Satan, but of Antichrist; for in perceiving the apocalyptic character of the view, its temporal sweep - comprehending all medieval and modern history-is suggested.

In fact, we must look back beyond Barruel, since already in the eighteenth century that movement which the political advance of secularism turned into Ultramontanism - the Catholic Counter-Enlightenment - perceived the origins of philosophisme to lie in the Protestant Reformation, with what was held to be its at least implicit claim to the use of untrammelled individual judgement. In preRevolutionary France, notions of conspiracy, which bound toleration-seeking French Protestants and philosophes to the same target, were already to be found in conjunction with the historical argument. ${ }^{40}$ But Counter-Enlightenment is not to

\footnotetext{
${ }^{37}$ Lord Acton to Newman, [June 12, 1862] letter, in L.D., XX, 206.

38 The role of moral character in the development and use of the intellect is a constant element in Allies's thought, perhaps most clearly in A Life's Decision, where he is careful to hold in juxtaposition, and sometimes in contrast, accounts of intellectual and moral development, and where he attests, from experience, to the influence of the latter upon the former. See, for example, 58-68. The matter is extensively explored with reference to the Oxford Movement as a whole in a recent work of James Pereiro, 'Ethos' and the Oxford Movement: At the Heart of Tractarianism (Oxford, 2008). Though Allies is not spoken of in that work, his writing might have clearly illustrated its arguments.

${ }^{39}$ Gough, Paris and Rome, 68-73; Geoffrey Cubitt, 'God, Man and Satan: Strands in Counter-Revolutionary Thought among Nineteenth-Century French Catholics', in Catholicism in Britain and France since 1789, edited by Frank Tallett and Nicholas Atkin (London, 1996), 135-50. Gough chooses merely to focus on the more incredible beliefs of conspiracy theorists. Cubitt has the merit of suggesting the capacity of this conspiratorial interpretation of la Révolution to develop varying patterns of historical thought.

40 McMahon, Enemies of the Enlightenment, 43-45, 77-78.
} 
be commented on without reference to its creative antagonising agent. The early Enlightenment period saw Christoph Cellarius finally make of the medium aevum, which had been in the process of creation since the Renaissance, an enduring historiographical tool. This medium aevum was given its character when the 'Renaissance sense of the past' ${ }^{\text {'1 }}$ became the Enlightened historical narrative, with its excoriation of "the long night of "barbarism and religion", 42 which might, conveniently, be seen to coincide with the one thousand, two hundred and sixty years of the reign of the papal Antichrist so often spoken of in Protestant millenarianism. ${ }^{43}$ Thus the Ultramontane and, as Ultramontanism triumphed, the Catholic historical landscape was all but visible in its essentials. It remained only to reverse the values being expressed. ${ }^{44}$ Aided by Romanticism, medievalism became the intellectual instrument for a projected reconstruction of the nineteenth century, while modernity, deriving from the Renaissance or the Reformation, was exposed as the usurping religion of the latter days. Nineteenth-century Catholicism's immense enrichment in its thought, its devotional practice, its art, and many other areas of its life by this ressourcement is much discussed, and in such discussion its polemical value should not be forgotten. The 'Middle Ages' was an instrument of discourse universally endorsed, but which, with Catholic transvaluation, might serve as a provocation of the enemy, an outreach to others, a malleable image of the good that was being fought for, an arsenal of intellectual weaponry, and, in its complementary depiction of the antithetical modernity, a confirmation of apocalyptic belief.

That Allies's medievalism served chiefly the last of these functions was made clear in an essay entitled 'Christian and Antichristian Education', written shortly after his conversion to indicate his interest in the, as yet, merely projected Catholic university in Dublin. The essay, at an early point, offers a brief exposition of the teaching of Bonaventure on human knowledge and its divisions. Its assertion of the primacy of revealed truth rendered it appropriate to 'make use of [...] as a standard' by which modern thought could be evaluated. ${ }^{45}$ However, Allies's purpose was not primarily a defensive eulogy of the Middle Ages, but an assault on modernity through an exposing of its intellectual, moral, and, indeed, supernatural origins. The adjective 'Antichristian' referred to a personal being, not an abstraction. Conformed as it was, in general, to Catholic narratives of 'l'origine et la propagation du mal en Europe, depuis la Renaissance' (to make use of the title of a very much longer work on the same topic, also of the $1850 \mathrm{~s}$, by l'abbé Gaume), Allies's piece displayed the historiographical flexibility of his school.

Allies accepted the Catholic commonplace of attributing l'origine $d u$ mal substantially to Protestantism. However, as one who had wrestled with the Anglican tradition, he was too well acquainted with earlier Protestant thought to allow its

\footnotetext{
41 Peter Burke, The Renaissance Sense of the Past (London, 1969).

42 John G. A. Pocock, The Enlightenments of Edward Gibbon, 1737-1764, the first volume of Barbarism and Religion (Cambridge, 1999), 4.

${ }^{43}$ For those concerned with the subject of historiography, an interesting introduction to this topic is provided by Howard Hotson, 'The Historiographical Origins of Calvinist Millenarianism', in The Later Reformation, the second volume of Protestant History and Identity in Sixteenth-Century Europe, edited by Bruce Gordon (Aldershot, 1996), 159-81.

44 The eighteenth century saw a more supine approach, which was content to modify the narrative of the philosophes. For exemplification, see Michael Printy, Enlightenment and the Creation of German Catholicism (Cambridge, 2009), 186-200.

${ }^{45}$ Allies, Per Crucem, II, 118.
} 
vulgar identification with the contemporary secularist beliefs against which he strove. His reservation on this matter simultaneously expressed agreement with yet another commonplace in the Ultramontane accounts of the rise of modernity: it could not be adequately explained without reference to supernatural evil. The Reformation had indeed assailed the principles of sound thought, 'of authority, of tradition, of deduction and development,' and by it 'the real standard [of truth] became the mind or feelings of the individual'. However, if the Reformers were hardly to be forgiven, it could still be said of them that they knew not what they did.

We are far, indeed, from asserting that Luther knew what he was about. There was a great and subtle and combining spirit using him as an instrument, who had formed his plan, a vast and skilful one, though the agent had none. ${ }^{46}$

If this treatment of Protestantism spoke of the author's Englishness, much more did his further account of the rise of modernity. The French Revolution was absent from it and even the Enlightenment was merely anticipated, in mention of Descartes. Allies is among the many who have found the most noteworthy call to modernity in Protestant England, in Francis Bacon's 'call to search for knowledge as power over nature'. ${ }^{47}$ In focusing its condemnation on the figure of Bacon, his historical view was kept within a familiar idealist structure; but it opened the possibility of encompassing polemically attractive economic and social phenomena. Allies perceived in Bacon's enthusiasm for induction an extension of the religious subjectivism introduced by Protestantism into other areas of human thought; and the origins of a scientism which subverted the predominantly deductive 'sciences of mind, of morals, and of theology'. However, it was also a scientism which gained its devotees by means of its technologies, promising 'a material prosperity beyond what the world had yet seen'. This had, he declared, become the true religion of England ${ }^{48}$ and he was able to illustrate his claim with some vividness by speaking of the devotion manifested in Hyde Park at the Crystal Palace Exhibition. ${ }^{49}$

This focus on English history, with an understanding of Protestantism in its temporal specificities and an inclination to accommodate the phenomena of economic and social history, provokes the thought that Allies might have given the Ultramontane generation a Catholic history of England to replace Lingard's timid, apologetic whiggery. However, Allies - who was responding to Archbishop Cullen's desires for Irish education - was as yet no historian by avocation and, indeed, might most profitably have been employed as a controversial apologist, a possibility he continued to entertain for another decade. Newman thought the friend for whom he sought a post in the Catholic University equally capable of applying himself to history, philosophy, or the classics. At length, however, Allies was invited to act as lecturer in the philosophy of history, a post which would not require him to relinquish his secretaryship at the Catholic Poor School Committee. ${ }^{50}$ Though Allies already inclined somewhat towards history, this field of scholarship was presumably assigned chiefly in view of the rector's perception of his institution's requirements; for

\footnotetext{
46 Allies, Per Crucem, II, 123-24.

${ }^{47}$ Charles Whitney, Francis Bacon and Modernity (New Haven, CT, 1986), 1.

48 Allies, Per Crucem, II, 124.

49 Allies, Per Crucem, II, 121-22, 139.

50 Newman to Allies, 20 April 1851; Newman to Archbishop Cullen, 28 April 1851; Newman to Allies, 18 May 1854; in L.D., XIV, 262; XIV, 267-70; XVI, 136.
} 
Newman was obliged to explain to his new lecturer what it might encompass and it how it might best be investigated. Allies's eventual contented adoption of his designation as a philosopher of history precluded further extended attention to insular history. He might though still have occupied himself with the study of the modern period. In 1860, Allies's development of his lecturing for the Catholic University seemed to be leading him towards a study of the medieval period from the ninth to the thirteenth century, already mentally named the 'Formation of Christendom'. It was to serve as an introduction to another study, this time of the modern period, which would describe, as he put it (using the words of the revered Donoso Cortés), 'le morcellement et le fractionnement de la république chrétienne'. ${ }^{51}$ The view he had briefly sketched of the triumph and fall of European civilisation almost a decade before in 'Christian and Antichristian Education' was still, it seems, the one he wished to paint. It was Newman, a guide more authoritative than any other for Allies, who successfully obscured his vision of it.

Newman's intervention consisted of a questioning of Allies's vision of those heights constituted by the peaks of the medieval achievement that would serve to give force to a depiction of a descent into the depths of modernity. Newman was never possessed of such a contrasting vision. He found no adoption of medievalism required for his own eschatological condemnation of modernity, in which the political and intellectual developments of the eighteenth and nineteenth centuries sufficiently manifested the character - but not yet the presence - of Antichrist. ${ }^{52}$ An intellectual formation in early nineteenth-century Oxford did not particularly encourage medievalism, which was certainly extrinsic to the Oxford Movement and no more than frequent among his new, Catholic co-religionists. Oxford formed him in the classics, patristic studies - the Anglican forte-and the Church of England's theology. Christian belief modified his enthusiasm for the classics; but he was firmly attached to what had been gained in the spoiling of the Egyptians, holding it to be indispensable to intellectual activity and pedagogy. Ultramontanism's marked anticlassicism, ${ }^{53}$ certainly as exemplified by l'abbé Gaume's desire to displace the pedagogical use of pagan literature, ${ }^{54}$ was repugnant to him. It was possible for Newman substantially to omit the Middle Ages, passing from the classics to patristic study, motivated and directed by his engagement with Anglican theological tradition. It is this last circumstance which lends some justification to his own doubt that his writings were 'fit for any but English men', who were acquainted with that post-medieval tradition. ${ }^{55}$

Newman did not merely lack propulsion towards a medievalist stance; he was, for reasons principled and practical, at least markedly suspicious of this constituent of Ultramontane ideology. Ian Ker, in speaking of Newman's discussion of medievalism with Allies, rightly perceives that the former's concern was with an inclination in contemporary Catholic medievalism to place improper confidence in worldly power, particularly when considering the question of establishment. ${ }^{56}$ When, in 1860 ,

\footnotetext{
${ }^{51}$ M. H. Allies, Allies, 108-10; Allies to Newman, 9 November 1860, in L.D., XIX, 420.

52 Colm McKeating, Eschatology in the Anglican Sermons of John Henry Newman (Lampeter, 1993), $27-35$.

53 For which see Gough, Paris and Rome, 62-63.

54 Newman sarcastically mused, in a letter to Cullen, if Gaume intended 'Aristotle to be given up with the rest'. Newman to Cullen, 16 September 1851, in L.D., XIV, 357-58.

${ }_{55}$ Newman to Allies, 30 November 1879, in L.D., XXIX, 206-07.

56 Ian Ker, John Henry Newman: A Biography, paperback edition (Oxford, 1990), 494-95.
} 
Newman received from Allies a sketch of his projected two-part work, he entered into a correspondence with him on its central 'theory' and, in the course of it, made clear his deviation from his friend's medievalist beliefs. He firmly rejected the notion that the Middle Ages constituted a realisation of Christianity of such a sort that its exemplary character was uniform and perennial. The era had no providentially granted character which made it - in any way that historical investigation could establish-less vulnerable to the power of sin or more conducive to the purpose of Christianity: the salvation of souls. It was an age like any other between the Incarnation and the Second Coming. ${ }^{57}$

This assertion of the inability of unaided human reason to render meaningful, and thus historical, the phenomena of the Civitas Terrena was perhaps intended by Newman to serve merely as a corrective caution from the field of the theology of history. Yet he was justified in his concern that his expression of his views might have been 'crude and hasty', ${ }^{58}$ appearing as a fundamental rejection of medievalism, which had, after all, gained the profound commitment, at many levels, of so many of his coreligionists. The epistolary form of Newman's remarks will, no doubt, excuse a failure to illustrate any inducement to Catholic study of the medieval period. As to their crudeness, the Augustinian argument was rendered too comprehensive, as Allies observed, appearing plainly to reject his own belief about what made the study of history, with its commonly received political content, of consequence: that, as an activity of a mind enlightened by revelation, it could give some degree of meaningfulness and usefulness to the entirety of the content of a period in which the citizens of the two cities coexisted. ${ }^{59}$ After all, the Church, in practice and with authority, clearly found characteristics of the medieval period, and not merely individual phenomena, to be good per se. Indeed, Allies's intellectual and spiritual mentor was laying down precepts that precluded the kind of history he assumed he should practise. As will be recorded below, he had done so before. If Newman's more striking, strictly religious argumentation rendered his case weak, the more conventional contemporary objections he nurtured against Ultramontanism's medievalist ideology were clearly present; medieval norms, if 'imposed out of season' on nineteenth-century societies, would prove counter-productive. The spirit of the age was not to be so defiantly resisted. ${ }^{60}$

Newman had stated at the beginning of his response to Allies's academic plans that he was, in giving his opinion, doing no more than encouraging discussion and reflection about a project he found commendable. Allies might have so used it; he entertained and acknowledged some doubts about his own position, occasioned by the late medieval failures of papal theocracy. ${ }^{61}$ However, he instead responded with a complete and permanent abandonment of his intention to write on the high Middle Ages. If this is surprising, Allies's abandonment of the intended Antichristian characterisation of the post-medieval period appears even more remarkable; for, in this, Newman's fundamental views were hardly at variance with his own. At any rate, he was indeed never to write at length on the periods which, until 1860, had formed, under the influence of his apocalyptic belief, the focus of his thought. If, as Mary

\footnotetext{
57 Texts of Allies's responses are joined to those of Newman's letters in M. H. Allies, Allies, 111-41.

${ }_{58}^{5}$ M. H. Allies, Allies, 130.

${ }^{59}$ M. H. Allies, Allies. See especially 118.

${ }^{60}$ M. H. Allies, Allies. See especially 121, 124-25.

61 M. H. Allies, Allies, 119.
} 
Allies observed, '[t]he impression these several letters [of Newman] conveyed to my father lasted as long as his life ${ }^{, 62}$ and effected a decision never revoked, a previous submission he had made to Newman's opinion on more fundamental matters of historical method proved much less complete. The volumes of that Formation of Christendom which were actually written and published indicate clearly enough that, despite a declared wish to submit, Allies never internalised Newman's view that, notionally at least, it is necessary for the historian to draw a distinction between the data of and the concepts developed in a study, and their religious application; that history was not essentially theology. If a particular apocalyptic exposition of history was abandoned, at least as a directive of his scholarly writings, a broader inclination to practise history as a sacred science, deriving fundamental data from revelation, remained.

\section{The Philosophy of History and Divine Providence}

In 1854, as Allies puzzled over the nature of the discipline he was being assigned to teach in Dublin, Newman attempted, as he was to again in 1860, to redirect his friend's historiographical thought. The guidance offered at this earlier point was, if brief, more positive and thus more revealing of Newman's own thoughts on history writing. Allies, rather misled by Newman's own initial attempt to offer a definition of the philosophy of history, concluded that it might be described as 'history viewed by the lights of final causes'. ${ }^{63}$ Newman, however, quickly pointed out that his own, now regretted, reference to providence did not indicate that by speaking of the philosophy of history he wanted a reassertion of providentialist history. ${ }^{64}$ Why then had Newman designated Allies's subject matter as the 'philosophy of history', rather than merely as 'history'? The former term suggested to Allies, quite understandably, a determinist understanding of the past, which, in a Catholic context, was a comprehension of history as directed by divine providence. Newman's thinking is probably best explained with reference to contemporary historical thought in the English universities. Here, determinist interpretations of the past - unless, of course, they were of the insular sort, disclosing the activity of a whig, Protestant deity-were unwelcome. Methodologies serving a zeal for inductive study were not. ${ }^{65}$ Newman seems to have believed that this characteristic of English historical scholarship - an adherence to the British empiricist tradition - might be modified by an introduction of a concern with establishing the laws of history. In fact, English historiography steadfastly declined to move in such a direction, which would have aligned it with French Positivism. ${ }^{66}$ Newman, however, entertained hopes that such a development would open the way for religious interpretation. He rejected Allies's desire to speak of final causes by assuring him that he might

[d]epend upon it, when once the laws of human affairs are drawn out, and the philosophy into which they combine, it will be a movement worthy of the

\footnotetext{
${ }^{62}$ M. H. Allies, Allies, 111.

63 Allies to Newman, 10 November 1854, in L.D., XVI, 292.

64 Newman to Allies, 11 November 1854 and 16 November 1854, in L.D, XVI, 292-93 and 297-98.

65 Philippa Levine, The Amateur and the Professional: Antiquarians, Historians and Archaeologists in Victorian England, 1838-1886, paperback edition (Cambridge, 2002), 76-77.

${ }^{66}$ Hayden V. White, 'Collingwood and Toynbee: Transitions in English Historical Thought', English Miscellany, 8 (1957), 149-50.
} 
Lawgiver, but if we begin speaking of Him first of all, we shall never get at His laws. I can quite understand a professor drawing religious conclusions from historical laws or ordinances, as from physical but he must first find his laws. ${ }^{67}$

Adherence to the principles on which the natural sciences were conducted was explicitly commended; laws were to be established by induction and the matter of the ends they served left open. Only at this point might the philosophy of history achieve that religious purpose which, indeed, Newman sought. Though he had previously spoken of mere facts, rather than laws derived by induction, as the material with which an historical writer worked, he had long insisted - and therein well-exemplified the Tractarian belief in 'ethos" ${ }^{68}$ - that to write a work of value it is necessary for it to express the convictions which the historian's character have shaped. It is, he said, necessary for one's exposition to be 'colour[ed...] with one's own mind, to give a tone to it' ${ }^{69}$ To Allies he complained that Friedrich von Schlegel's Philosophy of History lacked this in a consistent way; he found 'that it has no view'. Gibbon he held up as an exemplary philosopher of history, as writing 'with reference and subservience to a certain philosophy', adding 'and a bad one'. ${ }^{70}$

Newman's counsel reflected a belief that there was an historiographical area in which Catholic and secular learning might possess common ground, part, no doubt, of a wider belief that the Church - to use the imagery of Newman's Oratorian confrere, Frederick Faber - might adapt itself to the straying age, and go 'along with the world [...] in so far as it is allowed', with the hope of returning it to the Catholic fold. ${ }^{71}$ Allies's disposition towards the spirit of the age, on the other hand, was consistently and profoundly confrontational. His 'Christian and Antichristian Education' of a few years before devoted its opening paragraphs to declaring the complete irreconcilability of his society's thought with Catholicism, ${ }^{72}$ while the rest of the work depicted the chasm. The programme for intellectual formation advanced in that work noticed only the moral and intellectual corruption of the opinions of the age, which Catholic thought, particularly when moulded by fidelity to its medieval heritage, did not utilise, but rather, secure in the possession of an authentic source of truth, judged.

However, Allies possessed little of his own to guide him in forming a clear notion of how the philosophy of history might be defined and, as ever, was unable to run against his mentor's direction. Thus he consented to pronounce, in his 'Inaugural Lecture on the Philosophy of History', delivered in Dublin, an abjuration of the view set forth in 'Christian and Antichristian Education'. Allies simply declared his willingness to adhere fully and undeviatingly to Newman's recommended historiographical practice. The history of historiography which opened the lecture was built on a somewhat vague stadialism, to which was added an unconvincing attempt to attribute a transition to a universal, philosophical history to Christianity. Improbably, Gibbon was included as an exemplifier of such Christian history. ${ }^{73}$ From

${ }^{67}$ Newman to Allies, 16 November 1854, in L.D., XVI, 297-98.

${ }^{68}$ See above in note 38 .

69 Newman to James Hope, 6 November 1843, in L.D., X, 12-14.

${ }^{70}$ Newman to Allies, 13 September 1854, in L.D., XVI, 244.

71 Frederick William Faber, The Precious Blood or the Price of our Salvation, new edition (Philadelphia, 1959; Rockford, IL, 1978), 27-28.

72 Allies, Per Crucem, II, 113-15.

73 Allies, Christendom, I, 2-19. 
offering indication of the congruity of his own history with that of the Enlightenment era, Allies passed to pronouncing well the shibboleths required by the nineteenth century. It was necessary to proceed 'by a cautious and conscientious induction of facts' closely resembling 'the induction on which the physical sciences are built'. There was even a declaration of willingness to follow Bacon (a discreetly unnamed 'famous philosopher') in his renunciation of the quest for final causes - as commended by Newman. In the end, it was Newman's description of the philosophy of history, which would have proved acceptable to some of the staunchest enemies of Catholicism, that was declared for. 'It rests on a basis of facts; it results in a science; the scope of which is to set forth the laws by which the political and social world is governed. ${ }^{, 74}$

While the Dublin inaugural indeed contained Allies's declaration of a willingness to follow Newman, it also contained indication that he was hardly comfortable about where he was being led. He was emphatic that he desired to write as a Catholic, and with militancy. His philosophy of history would indeed be philosophy, possessed of its distinction from theology; but it would be the product of a mind conscious of the truth of divine revelation. His work would stand in opposition to those whose philosophies of history 'either ignore the existence, or disfigure and misrepresent the operation, of the City of God'. ${ }^{75}$ Most notably, providence, admittedly a revealed truth, was to gain admittance, since it was also a truth demonstrable by reason, as were those others which had to be accepted by any 'great and true historian', the existence of 'a free will of man' and a cosmic conflict of good and evil in which it participated. $^{76}$ The apocalyptic dualism so often pointed to as pervading Ultramontane thought ${ }^{77}$ was to be fundamental to its historiography.

Still, all of this might have been considered to remain within Newman's parameters, constituting a declaration of the 'view' or 'tone' that would be adopted. Allies had indeed resolved to accept the historiographical direction Newman had given and, in the long labour of the production of his magnum opus, attempted conscientiously to follow it. However, the student's effort was far from gratifying his master. His difficulty lay in the requirement of Newman's scheme for the 'facts' to produce 'laws', which, it was at least to appear, they had generated spontaneously. A manifestation of 'view' at this point fundamentally undermined the rhetoric of scientific history. Unfortunately, Allies had no ability to perform the necessary task of inventing such laws or, more probably, never truly saw the need for such entities, so prominent were the workings of divine providence in his mind. The laws which governed human affairs were already sufficiently clear to him by virtue of his Catholicism. His inclination to what Newman, very privately, dismissed as historically uninteresting 'sermonising ${ }^{78}$ is clear from the beginning of the first volume of the Formation of Christendom. The first of the lectures (prefixed by the inaugural) that constitute it offers a eulogising depiction of the Roman imperial political order that in truth was, quite transparently, the

\footnotetext{
74 Allies, Christendom, I, 21-23.

75 Allies, Christendom, I, 34-36.

76 Allies, Christendom, I, 24-26.

77 See, for example, Jeffrey P. Johnson, 'Introduction: Juan Donoso Cortés and the Philosophy of Counterrevolution', in Donoso Cortés, Selected Works of Donoso Cortés, edited and translated by Jeffrey P. Johnson (Westport, CT, 2000), 19-22.

78 Newman to Canon John Walker, 6 June 1869, in L.D., XIV, 265-66.
} 
Ultramontane's idealised conception of the order of medieval Christendom under its papacy. The inferiority of the nineteenth-century's political order was emphasised. ${ }^{79}$ Clearly the laws which created such a society in the ancient world, one that was at once prophecy and partial realisation of what was prophesied, could be none other than those of divine providence. The early volumes of the Formation of Christendom, as a whole, made it plain that their extremely learned and extensive depiction of antiquity was formed to depict the nature of Christianity's salvific mission and the circumstances and manner in which this was carried out. Their concern was entirely with the Civitas Dei. At length, as his work progressed, conscious that no devotion to the expounding of historical facts would serve to establish his vision of the operations of God's providence, Allies explicitly called for the acceptance of the Christian revelation as the prerequisite for appreciation of his work. Thus, as he commenced one of the later volumes in the series, he wrote 'for those to whom history is intelligible', since they had received the doctrines he employed it to teach and confirm. To others, he had concluded, '[t]he lessons of history fail to convey any definite impressions. ${ }^{, 80}$

If the Formation of Christendom gave, on every page, evidence that its author was exclusively concerned with the divinely directed and revealed history of the Civitas $D e i$, it equally gave evidence that the sources for the pointless study of history focused on the Civitas Terrena had been very extensively quarried indeed for his purpose: the promise to raise the edifice on facts had not been forgotten. This characteristic of the work was, no doubt, a substantial cause of its failure to gain the enthusiasm of those, the hotter sort of Catholic, who lacked interest in Catholic history's relationship to other streams of contemporary scholarship. The later volumes of the series focused wholly on establishing the assertion that the Roman See was 'the root, the bond, and the crown of Christendom'. ${ }^{81}$ However, those who would have welcomed such historical knowledge as illustrated and convincingly confirmed Catholic teaching on the papal office encountered the fruits of Allies's enduring devotion to facts. Allies's method of wading through Mansi's edition of papal letters - supplemented by the works of ancient writers and the more monumental displays of German, French, and Italian historical scholarship (succinctly listed in the introductions to the volumes) to produce an immense narrative was scarcely helpful to readers seeking effective polemical points.

\section{Conclusion}

The term 'Ultramontane' has very often been used by writers disposed to reduce the phenomena of nineteenth-century English Catholicism to a party system. The Ultramontanes take their place in a confusing tangle of ecclesiastical parties, often tendentiously characterised-Old Catholics, Converts, Anglo-Gallicans, Ultramontanists, and Liberals. For good measure, ethnic division appears too. The view produces a lack of interest among those concerned with wider themes in religious

\footnotetext{
79 Allies, Christendom, I, 41-62.

80 Allies, Christendom, VII, 3, 5. This volume, published in 1890, bears the title Peter's Rock in Mohammed's Flood: From St. Gregory the Great to St. Leo III.

81 This quotation is from the subtitle of the fifth volume of the Formation of Christendom, published in 1887 and entitled The Throne of the Fisherman Built by the Carpenter's Son, the Root, the Bond, and the Crown of Christendom.
} 
history than those of ecclesiastical politics. ${ }^{82}$ The present study has, assisted by the work of those who have spoken of a 'New Catholicism', insisted that Ultramontanism must not be so reduced. Its increasing ascendancy over the Catholic world must be held in mind, as must its significance as the most egregious response of Christian churches to the emergence of nineteenth-century secularism. Allies, who might be said to have been an Ultramontanist while still a Tractarian, reminds us that it was part of a rather larger whole, within which such British phenomena as the Oxford Movement and the Scottish Disruption-and much else - can be placed. Its significance extends to the history of civil as well as ecclesiastical politics, and to social, cultural, and - the concern of this essay-intellectual history.

The particular story told here, of Allies's failure to leave us a thoroughly Ultramontane vision of history from an English pen, has, it is hoped, added something to an understanding of the content of Ultramontanism's historical vision and, more generally, helped to explain the perennial, pervasive difficulties that the realisation of Ultramontane objectives encountered, the consideration of which has led scholars of the present day to speak of its place within modernity. It was always bound to a partially positive relationship with that which it struggled against, absorbing too much from it. Seen too is its weakness: zeal in the struggle always flagged. Consistent hostility towards the spirit of the age was possible neither to Newman, who had a university that could attract young Irishmen to establish, nor to Allies, who desired academic approval for his work. By training, after all, they were 'Anglican clergymen [...], not field generals warring against society'. ${ }^{83}$ With regard to Newman, we are also reminded that for all his influence on thought about the historical dimension of theological study, he devoted but little of his mind to the question of how history was, or ought to be, written, and in speaking of this matter he showed himself as no more than a learned man of his own era and culture.

More interesting than Allies's failure is his assertion - much weakened by his personal relationship to Newman - of belief in a providentialist understanding of history and the constancy of his inclination to express it. It is neither appropriate nor necessary here to emphasise the extent to which providentialist notions permeated the thought not merely of its Catholics, but of the English-speaking world at large in the nineteenth century. That particular form of providentialist thought, apocalyptic, as it existed among English Catholics, stands in need of investigation, perhaps because it existed in more diffuse form among them than it did among Protestants, whose writings on the topic are generally identifiable at a glance. The apocalyptic dimension of the contemporary Marian cultus, commented on with regard to other areas, ${ }^{84}$ was certainly extensively present in England. ${ }^{85}$ Allies's association of modernityperceived as the characteristics of the post-medieval world - with Antichrist, together

\footnotetext{
${ }^{82}$ See, for a brief example, Damian McElrath, The Syllabus of Pius IX: Reactions in England (Louvain, 1964), 6-8. As a further example, Mary Heimann's work, Catholic Devotion in Victorian England (Oxford, 1995), chapter 1, commends itself by its inclination to simplify matters by regarding the conflict of Ultramontanism and its opponents as fundamental.

83 Jon Butler, Awash in a Sea of Faith: Christianizing the American People (Cambridge, MA, 1990), 168.

${ }^{84}$ Sandra L. Zimdars-Swartz, Encountering Mary: From La Salette to Medjugorje (Princeton, NJ, 1991), 163-270.

${ }^{85}$ In addition to references to Marian apparitions, such as are to be found in Bishop William Ullathorne's The Holy Mountain of La Salette: A Pilgrimage of the Year 1854 (London, 1855), chapter 9, mention might be made of English interest in the apocalyptic ideas influenced by the Marian devotion of Louis-Marie Grignion de Montfort. See, for example, Frederick William Faber, introduction to The Month of Mary Conceived without Sin (London, [1855]).
} 
with the medievalism of the Formation of Christendom, which supported this view of the modern period, suggest that the historical writings of English Catholics are another important source for the study of their apocalyptic beliefs. Allies's apocalypticism, and, more generally, the pervasiveness of his belief in the providential ordering of history, suggests strongly that our understanding of the nineteenthcentury English Catholic perception of the past, created by many with no pretensions to be called historians, stands in need of revision. Certainly, this will hardly be achieved by endorsing a canon in which such writers, widely commended beyond the bounds of the Catholic community, such as Lingard and Acton, are held to stand pre-eminent. 